Article

\title{
Investigation of the Relationship between Bacteria Growth and Lipid Production Cultivating of Microalgae Chlorella Vulgaris in Seafood Wastewater
}

\author{
Thi Dong Phuong Nguyen ${ }^{1}$, Duc Huy Nguyen ${ }^{2}$, Jun Wei Lim ${ }^{3}{ }^{10}$, Chih-Kai Chang ${ }^{4}$, \\ Hui Yi Leong ${ }^{5}$, Thi Ngoc Thu Tran ${ }^{1}$, Thi Bich Hau Vu ${ }^{6}$, Thi Trung Chinh Nguyen ${ }^{1}$ \\ and Pau Loke Show ${ }^{5, *(D)}$ \\ 1 The University of Danang, University of Technology and Education, 48 Cao Thang St., Danang 550000, \\ Vietnam; ntdphuong@ute.udn.vn (T.D.P.N.); ttnthu@ute.udn.vn (T.N.T.T.); nttchinh@ute.udn.vn (T.T.C.N.) \\ 2 Institute of Biotechnology, Hue University, Hue 530000, Vietnam; ndhuy@hueuni.edu.vn \\ 3 Department of Fundamental and Applied Sciences, Centre for Biofuel and Biochemical Research, \\ Institute of Self-Sustainable Building, Universiti Teknologi PETRONAS, Seri Iskandar 32610, Perak Darul \\ Ridzuan, Malaysia; junwei.lim@utp.edu.my \\ 4 Department of Chemical Engineering and Materials Science, Yuan Ze University, No. 135, Yuan-Tung Road, \\ Chungli, Taoyuan 320, Taiwan; kevinvecent@gmail.com \\ 5 Department of Chemical and Environmental Engineering, Faculty of Science and Engineering, \\ University of Nottingham Malaysia, Jalan Broga 43500 Semenyih, Selangor, Malaysia; \\ isabellelhy@gmail.com \\ 6 Danang Department of Science and Technology, 53 Nguyen Thi Minh Khai St., Danang 550000, Vietnam; \\ vubichhau@yahoo.com \\ * Correspondence: showpauloke@gmail.com or PauLoke.Show@nottingham.edu.my
}

Received: 21 April 2019; Accepted: 10 May 2019; Published: 14 June 2019

check for updates

\begin{abstract}
Algae biorefinery is gaining much attention for the sustainable production of value-added products (e.g., biofuels, protein supplements etc.) globally. The current study aimed to investigate the relationship between lipid production and bacteria growth by an initial microalgae Chlorella vulgaris density culture in seafood wastewater effluent (SWE). According to our results, the initial C. vulgaris concentration in SWE influenced lipid accumulation. The concentration ranged from $25-35 \mathrm{mg} \cdot \mathrm{L}^{-1}$ which corresponds to SWE's chemical oxygen demand concentration of $365.67 \pm 3.45 \mathrm{mg} \cdot \mathrm{L}^{-1}$. A higher microalgae growth rate and lipid content of $32.15 \pm 1.45 \%$ was successfully attained. A higher lipid content, approximately double, was observed when compared to the control (16.8 $\pm 0.5 \%)$. Moreover, this study demonstrates that bacteria inhibited microalgae growth as the initial cell density stepped over $35 \mathrm{mg} \cdot \mathrm{L}^{-1}$, which also affected lipid accumulation. This study shows an optimal lipid accumulation attained at moderate Chlorella vulgaris density culture in SWE. Hence, wastewater treatment incorporating microalgae culture could be greatly developed in the future to achieve a greener environment.
\end{abstract}

Keywords: bacteria inhibition; Chlorella vulgaris; co-culture; lipid accumulation; wastewater treatment

\section{Introduction}

Lipid production is a key factor for the evaluation of microalgae culture causing ecological developments. The microalgae culture has several major aims: (i) enhancing the lipid accumulation for biofuel production, and (ii) using innovative techniques in order to reduce the cost of biomass production. However, the microalgae culture shows limitations: (i) a competitive source of water in crops of microalgae, (ii) a long harvesting period and (iii) the challenging feasibility of up-scaling [1]. 
With significant innovations in algae harvesting by the application of algae inoculation for the purposes of wastewater treatment and biomass production, the barrier in algae lipid accumulation might be critically concerned in the cultivation.

Several studies have reported various alternative techniques of microalgae culture for enhancing lipid accumulation and an extraction method to achieve the efficient lipid content [2,3]. Generally, the lipid accumulation is affected by nitrogen starvation in freshwater and/or seawater medium, the cell stress due to light illumination [4,5], $\mathrm{pH}$ and temperature [6-8] as well as nutrient compound [9]. Increasing the proportion of fatty acids is remarkably observed when there is an increment of light intensity in microalgae culture. Moreover, the resulting high lipid content is due to the regulation of nitrogen limitation and $\mathrm{pH}$ by $\mathrm{CO}_{2}$ concentration $[6,10]$.

However, most of the studies on microalgae culture had a limitation on culture medium. The medium that is artificially prepared was used in the lab-scale microalgae cultivation. With respect to this matter, the investigation of practical mediums, such as wastewater effluent, is of growing interest. Moreover, the lipid accumulation of microalgae was illustrated depending on essential nutrients, such as nitrogen [11-13], phosphate [14] and metal components [15]. Meanwhile, an important parameter, i.e., the major character of microalgae inoculum in culture medium that researchers have not yet figured out, constitutes the high potential of nutrients as well as initial cell density to examine the lipid accumulation.

The assimilation of nutrients from the wastewater source of microalgae cells for lipid production has been well-documented on the culture medium from artificial sewage with the photo-heterotrophic process. The lipid content increased up to $42 \%$ as Chlorella vulgaris was cultured from this process [12]. Furthermore, compared to the photo-autotrophic mode of microalgae culture, the photo-heterotrophic mode resulted in several advantages, such as a higher biomass growth rate and lipid production as well as easier biomass harvesting [16,17]. Various limitations with major lipid production by microalgae culture in wastewater have been reported, including environment stress and nutrient limitation among others.

Meanwhile, the effect of bacteria on lipid production in microalgae cultivation is of great interest. It is known that bacteria play an important role (such as blooming microalgae, enhancing auto-flocculation etc.) in the lipid accumulation when culturing microalgae in wastewater. In this study, the Chlorella vulgaris culture in wastewater is examined to elucidate the capacity of bacteria's stimulation of lipid production. The lipid content of various proportions of the initial microalgae concentration in seafood wastewater and bacteria growth inhibition are examined.

\section{Materials and Methods}

\subsection{Microalgae Strain and Wastewater Sample}

The cultivation of Chlorella vulgaris SAG 211-19 was performed in Sueoka medium according to the method described in our previous works [18-20]. The wastewater samples were taken from centralized seafood wastewater treatment in the Danang industrial zone, Vietnam. Their total suspended solid (TSS), total nitrogen (total-N) and total phosphorus (total-P) $\left(\mathrm{mg} \cdot \mathrm{L}^{-1}\right)$ were initially measured at $465.5 \pm 2.5,107.25 \pm 4.05$ and $11.04 \pm 1.5$, respectively. The initial concentration of aerobic bacteria and coliforms $\left(\right.$ CFU.mL $\left.{ }^{-1}\right)$ in this effluent were $(91.81 \pm 1.5) \times 10^{5}$ and $(5.81 \pm 0.4) \times 10^{4}$, respectively.

\subsection{Experimental Set-up}

Microalgae Chlorella vulgaris was obtained from the Sueoka culture broth (initial concentration of $\left.0.8 \pm 0.002 \mathrm{~g} \cdot \mathrm{L}^{-1}\right)$. It was then adjusted in the $2 \mathrm{~L}$ Erlenmeyer flask containing $1 \mathrm{~L}$ of seafood wastewater effluent (SWE) at different initial biomass concentrations starting from $20 \mathrm{mg} \cdot \mathrm{L}^{-1}$ with an interval of $5 \mathrm{mg}$. These initial concentrations were set up following the description in Nguyen et al. [19] in order to examine the influence of the initial content of microalgae cells on their growth rate, bacteria inhibition and lipid production. Hence, the calculation of the microalgae productivity ratio is based 
on the ratio of chemical oxygen demand (COD) concentration/microalgae inoculum concentration by using the methodology in [19].

Erlenmeyer flasks were incubated at $26 \pm 2{ }^{\circ} \mathrm{C}$ with fluorescent light of $150 \mu \mathrm{mol} \cdot \mathrm{m}^{-2} \cdot \mathrm{s}^{-1}$. One Erlenmeyer flask of SWE without microalgae strain was considered as a blank. The experiment was performed twice. The microalgae inoculum was cultivated for 14 days until the cells reach to the death phase corresponding continuously decrease in the number of cells. During the culture days, $5 \mathrm{~mL}$ of the suspension was withdrawn for the determination of cell growth rate and bacterial counts. To calculate the lipid production of microalgae inoculum in SWE, the suspension was drawn at $10 \mathrm{~mL} \times 3$ on the day where the cells started reach in the death phase.

\subsection{Analysis}

\subsubsection{Microalgae Growth}

The growth of each microalgae culture was daily measured for 14 days by dry weight concentration (DW), cell number and chlorophyll, following Nguyen et al. [19], so as to calculate the rate of microalgae depending on the cell productivity ratio. The specific growth rate $\left(\mu\right.$, day $\left.^{-1}\right)$ was calculated according to Equation (1) [21]:

$$
\mu=\frac{\ln \left(\frac{N_{2}}{N 1}\right)}{\left(t_{2}-t_{1}\right)}
$$

where $N_{1}$ is the cell density at time $t_{1}$ (cell. $\mathrm{mL}^{-1}$ for microalgae cell, CFU.mL ${ }^{-1}$ for bacteria); $N_{2}$ is the cell density at time $t_{2} ; t_{1}$ is the culture time 1 , day; $t_{2}$ is the culture time 2 , day.

\subsubsection{Total Lipid Content}

The total lipids were measured following the modified method of Folch used by Pruvost et al. [22]. Prior to avance, the lipid extraction, glass vials and the caps of the vials were rinsed with acetone using a dedicated tube, and they were then dried naturally (acetone was changed every 10 rinses). Three volume replicates of microalgae culture corresponding to 5-10 mg dry matter were sampled in glass vials and then centrifuged for $10 \mathrm{~min}$ at $3600 \mathrm{~g}, 20^{\circ} \mathrm{C}$. The supernatant was eliminated by the Pasteur pipette. While, the pellet was re-suspended in $2 \mathrm{~mL}$ of mixed chloroform/methanol $(2: 1, \mathrm{v} / \mathrm{v})$ and vortexed for $10 \mathrm{~s}$, the tubes were placed in an ultrasonic bath for $4 \times 30 \mathrm{~s}$. These steps were repeated to obtain a final volume of $6 \mathrm{~mL}$. To ensure a complete cell extraction, the vials containing $6 \mathrm{~mL}$ of suspension were covered by aluminium foil and incubated for $6 \mathrm{~h}$ under light agitation. The solvents were then evaporated under nitrogen at $40{ }^{\circ} \mathrm{C}$. To the vial was then added $1 \mathrm{~mL}$ of a mixture of chloroform/methanol $(2: 1, \mathrm{v} / \mathrm{v})$ and ultrasound was performed for $1 \mathrm{~min}$. Before centrifugation at 3600 $\mathrm{g}$ and $20{ }^{\circ} \mathrm{C}$, the supernatant was washed with $0.8 \mathrm{~mL}$ of $\mathrm{KCl}(0.88 \%)$. The lower layer was dried in another pre-weighed vial until reaching a constant weight. Thereafter, the total lipids were measured gravimetrically, and the lipid content was calculated. The experiment of lipid determination was performed at the day of microalgae culture when the cell reaches maximum biomass concentration. Moreover, the total lipid content was determined at the first growth phase of microalgae culture (0-4 days) and the second growth phase, as microalgae density greatly decreased, (5-14 days) in order to examine the change of lipid content at these two phases of the cell cultivation process.

\subsubsection{Lipid Analysis}

Triacylglycerol (TAG) analysis of extracted total lipid was performed by TLC silica gel matrix aluminium plates (Merck, Vietnam). The total lipid extracts were dissolved in $0.5-1.0 \mathrm{~mL}$ of hexane for TLC analysis. Pure green bean powder (Merck, Vietnam) was used as a standard and the lipids were separated on TLC plate by using a solvent mixture of hexane/diethyl ether/acetic acid (85:15:1, v/v/v), then the plate was heated at $150{ }^{\circ} \mathrm{C}$ for 5 min before visualizing under UV light. 


\subsubsection{Bacteria Count}

From the culture flask, $1 \mathrm{~mL}$ microalgae culture sample was collected and was then diluted for inoculation on plates. They were incubated for $24-48 \mathrm{~h}$ at $37^{\circ} \mathrm{C}$. The bacterial content was calculated by using the standard method of colony forming unit (CFU) counting on plates as to determine the aerobic bacteria and total coliforms [23]. In order to evaluate the growth inhibition of bacteria affecting the lipid production, its growth rate was determined according to Equation (1) as a function of microalgae culture existence time. However, changes in the number of bacteria in different phases, including the exponential phase (0-4 days) and decreasing phase (5-14 days), were recorded to calculate their growth rates in the culture medium.

\subsubsection{Water Quality}

The water quality was described in Nguyen et al. [20], in particular the measurements of TSS, total-N and total-P of wastewater samples were done according to the APHA/AWWA/WEF standard method [24]. The suspension of experimental effluents was recovered in order to determine the performance of TSS, total-N or total-P removal. Each experiment was conducted for 14 days; it was started from the Chlorella vulgaris flocs decanted in the bottom of the flasks. The efficiency removal $\left(\mathrm{E}_{r}, \%\right)$ of TSS, total-N or total-P was calculated as the capacity of total suspension removal based on the following:

$$
\mathrm{E}_{r}=\frac{\mathrm{C}_{i}-\mathrm{C}_{f}}{\mathrm{C}_{i}} \times 100 \%
$$

where $\mathrm{C}_{i}$ is the maximum concentration of TSS, total-N or total-P in suspension $\left(\mathrm{mg} \cdot \mathrm{L}^{-1}\right) ; \mathrm{C}_{f}$ is the final concentration of TSS, total-N or total-P in suspension as flocs decanted in constant $\left(\mathrm{mg} \cdot \mathrm{L}^{-1}\right)$.

\section{Results}

\subsection{Effect of Growth Rate of Initial Microalgae Cell}

The microalgae growth was evaluated according to our previously performed works as cells inoculum in seafood wastewater $[19,20]$. However, in order to illustrate the dependence on initial density of microalgae as being inoculum in SWE, the specific growth rate, $\mu\left(\right.$ day $\left.^{-1}\right)$ was calculated using Equation (1) and shown in Figure 1. Following the results in $[19,20]$, the flocculation process began with an initial biomass concentration of $20 \mathrm{mg} \cdot \mathrm{L}^{-1}$. This study approached a different appraisement of microalgae growth. Compared to the increment of initial density of microalgae in SWE, the rate of microalgae cells at day 5 , where the cells reached a maximum, illustrated a significant reduction from $0.65 \pm 0.013$ to $0.18 \pm 0.01 \mathrm{day}^{-1}$. It was noted that the microalgae cells might be prevented from growing in the division stage.

Many studies have reported the factors influencing growth rate and cell productivity, such as $\mathrm{CO}_{2}$ regime or aeration rate, nitrogen starvation and light condition $[25,26]$. In this study, our culture flask was set up following the factors listed in the aforementioned studies. However, these environmental factors might not play a crucial role in the change of biomass productivity in our microalgae culture. Obviously, a significant decrement in biomass concentration was observed by increasing the initial cell density. Also, the increase of the initial content of microalgae caused the slow reduction of bacteria. When the microalgae cell gradually reached the death phase, the bacteria aggregated these cells to flocs by way of extracellular polymeric substance layers preventing the stimulation of nutrients in cell division and conducting the auto-flocculation. It was proven that the increase in the microalgae growth rate has been indicated by the chlorophyll a content and biomass concentration. A significant decrease in biomass concentration, especially the chlorophyll a content of microalgae inoculum in SWE, was observed as an increase in the initial cell density. In addition, increasing the cell density significantly decreased the lipid content. This could be explained by the presence of bacteria which influenced the lipid synthesis (Table 1). 
Table 1. The characteristics of Chlorella vulgaris inoculum in SWE.

\begin{tabular}{|c|c|c|c|c|c|c|c|c|c|c|c|}
\hline $\begin{array}{l}\text { Initial Microalgae } \\
\text { Density }\left(\mathrm{mg} \cdot \mathrm{L}^{-1}\right)\end{array}$ & 20 & 25 & 30 & 35 & 40 & 45 & 50 & 55 & 60 & 65 & $\begin{array}{c}\text { Micro-Algae } \\
\text { in Sueoka } \\
\text { (Control) }\end{array}$ \\
\hline $\begin{array}{l}\text { Maximum biomass } \\
\text { concentration } \\
\left(\mathrm{mg} \cdot \mathrm{L}^{-1}\right)\end{array}$ & $820 \pm 12$ & $750 \pm 5.7$ & $560 \pm 10.0$ & $500 \pm 8.5$ & $500 \pm 17$ & $440 \pm 12.1$ & $270 \pm 15.2$ & $270 \pm 10.2$ & $250 \pm 10.45$ & $250 \pm 20.1$ & $800 \pm 25.5$ \\
\hline$\mu\left(\text { day }_{5}{ }^{-1}\right)^{a}$ & $0.6 \pm 0.016$ & $0.65 \pm 0.01$ & $0.61 \pm 0.012$ & $0.54 \pm 0.015$ & $0.52 \pm 0.02$ & $0.41 \pm 0.011$ & $0.32 \pm 0.014$ & $0.21 \pm 0.011$ & $0.188 \pm 0.016$ & $0.18 \pm 0.013$ & $0.57 \pm 0.02$ \\
\hline $\begin{array}{l}\text { Chlorophyll a } \\
\left(\mathrm{mg} \cdot \mathrm{L}^{-1}\right)\end{array}$ & $21.14 \pm 1.68$ & $20.45 \pm 2.5$ & $17.35 \pm 1.25$ & $14.5 \pm 2.2$ & $14.75 \pm 1.6$ & $13.75 \pm 1.5$ & $9.25 \pm 1.2$ & $9.72 \pm 2.1$ & $8.87 \pm 0.75$ & $6.8 \pm 0.5$ & $19.92 \pm 2.6$ \\
\hline $\begin{array}{c}\text { Lipid content (5-14 } \\
\text { days) }(\%)\end{array}$ & $32.15 \pm 1.45$ & $31 \pm 1.28$ & $32 \pm 1.55$ & $27.56 \pm 2.15$ & $25.5 \pm 2.02$ & $21.02 \pm 0.85$ & $17.25 \pm 2.25$ & $16.41 \pm 1.5$ & $17.2 \pm 1.5$ & $17.5 \pm 2.5$ & $16.8 \pm 0.5$ \\
\hline
\end{tabular}

${ }^{a} \mu\left(\right.$ day $\left._{5}{ }^{-1}\right)$ : Specific growth rate of Chlorella vulgaris measured at day 5 where the biomass concentration was maximum compared to that of the first day of culture. 


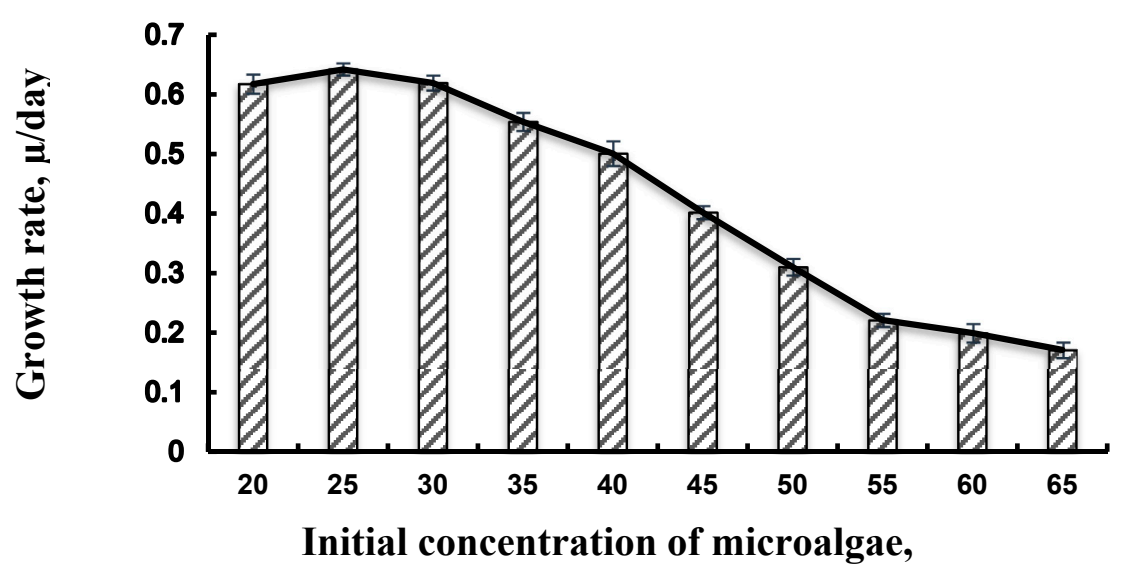

Figure 1. Specific growth rate of Chlorella vulgaris depending on initial biomass concentration.

During the first five days of cultivation, bacteria act as lysozymes to lyse macromolecules from SWE in order to create favorable conditions for supplying sufficient carbon dioxide to photosynthesis and smaller molecules for cell division [27]. This period of time allows a rapid cell division, and the microalgae that initially entered the SWE medium speedily reached the exponential phase and then achieved the maximum cell number [11]. As the initial cell density increases, bacteria could supply sufficient carbon dioxide and other nutrients for the cell division and thus limit the metabolic reaction. Starting from day 6 (period of 5-14 days), the microalgae growth began to approach the death phase. The cell division might cease instead of blooming microalgae with the support of the bacteria population.

\subsection{Effect of Initial Microalgae Cell and Bacteria Growth}

The various bacteria growth rates investigated in this study aims to explain the limitation of initial density of microalgae inoculum to bacteria population. It can be shown that the growth curves of aerobic bacteria and coliforms had the same style of illustration. Over the first four days of microalgae adjusting in SWE, the bacteria population at initial microalgae concentrations of 25,30 and $35 \mathrm{mg} \cdot \mathrm{L}^{-1}$ significantly increased compared to others. They were then greatly decreased as the cultures started to enter the fifth day; the culture had achieved the maximum cell concentration. On the other hand, all the other flasks had the bacteria content increase until the microalgae cell number rose to a maximum at day 5 , then gradually dropped to constant (Figure 2). This suggests that during the photosynthesis process, it is necessary to provide nutrients for cell division, while bacteria could play a role as an enzyme to accelerate this process [12,28]. Lipid accumulation will begin once the maximum cell concentration is reached in this division stage. This period of time allows bacteria to cease growing and to continue aggregating the cell [29].

Previous research reported that bacteria influence the microalgae growth [30,31]. Chlorella vulgaris was cultured in a wastewater medium containing various bacteria which affected the cell growth, in particular, the blooming of microalgae [19,20,32-34]. The higher the density of microalgae, the faster the auto-decantation to be happened. For initial concentrations of microalgae after $30 \mathrm{mg} \cdot \mathrm{L}^{-1}$, their growth rates significantly decreased (Figure 1). Similarly, the growth rates of bacteria with initial an density of microalgae from $30 \mathrm{mg} \cdot \mathrm{L}^{-1}$ also slowly decreased at the beginning of day 5 where the culture started to enter the death phase and the TSS removal performance reached to $90.5 \pm 1.5 \%$ at the highest initial concentration of microalgae inoculum (Table 1). It is suggested that with the high initial density of microalgae, the bacteria started to bloom microalgae, causing cell auto-flocculation. From Figures 1 and 2, the best result for a co-culture between bacteria and microalgae was observed at around 25 to $30 \mathrm{mg} \cdot \mathrm{L}^{-1}$ of initial microalgae concentration. 


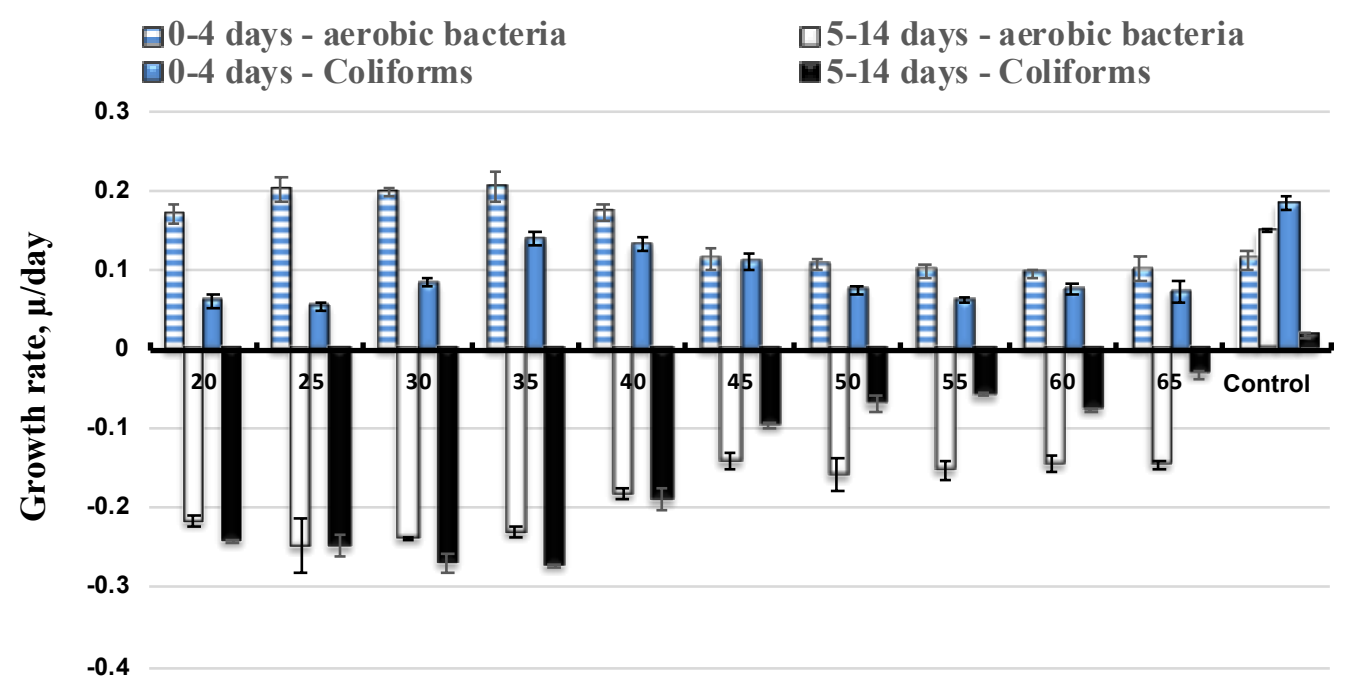

Initial concentration of microalgae, $\mathrm{mg} / \mathrm{L}$

Figure 2. Growth rate of bacteria population function to initial Chlorella vulgaris cell density following two period times of culture: (1) 0-4 days of culture and (2) 5-14 days of culture.

Moreover, the bacteria certainly enhanced the auto-flocculation process and improved conditions in flocs removal out of suspension. In Table 1, the results indicated the performances of TSS removal were gradually increased depending on initial microalgae concentration. Although the growth rate of microalgae strain was not a sign of flourishing following the initial cell density, the efficiency of TSS removal was favorable at $90.5 \pm 1.5 \%$ at the initial microalgae concentration of $65 \mathrm{mg} \cdot \mathrm{L}^{-1}$ in comparison to $88 \pm 0.7 \%$ at initial cell content of $20 \mathrm{mg} \cdot \mathrm{L}^{-1}$. These findings confirmed the presence of bacteria augmented the conditions for cell auto-flocculation and inhibited the lipid accumulation.

\subsection{Bacteria Inhibition to Lipid Production}

The primary goal for microalgae cultivation is mainly related to obtaining the highest lipid accumulation from cells. As a preliminary stage, bacteria-inhibited lipid production was investigated for Chlorella vulgaris inoulum with different initial densities. Compared to the lipid content of microalgae in Sueoka medium, these concentrations showed much higher lipid content. The maximum lipid percentage was up to $32 \pm 1.55 \%$ at the initial cell content of $30 \mathrm{mg} \cdot \mathrm{L}^{-1}$, as shown in Figure 3 . After that, the lipid accumulation showed a significant reduction for initial microalgae concentration from 40 to $65 \mathrm{mg} \cdot \mathrm{L}^{-1}$, values ranged from $27.56 \pm 0.3 \%$ to $32.15 \pm 0.21 \%$, emphasizing an important modification to lipid accumulation. The lipid content varied following the first stage (0-4 days) of microalgae inoculum as cells started to divide in the final stage (5-14 days) (cells went to the death phase). The accumulation of lipids on the first four days occurred less than on the final stage of culture. The lipid content was around $22 \%$ at the first stage for initial cell concentrations less than $30 \mathrm{mg} \cdot \mathrm{L}^{-1}$ while it showed an average of $31 \%$ at the last stage. A variation of approximately $10 \%$ constitutes a significant contribution to the aim of lipid production.

According to [12], a decrease in microalgae growth induced an increase in in lipid synthesis, owing to metabolic reserves for the cell synthesis from lag phase to the stabilized phase under photosynthesis. Our results in this study were in agreement with the literature, with the higher cell density of initial concentration resulting in nutrient synthesis during cell division and demonstrating the difficulty of lipid accumulation. However, the lipid concentration had not much variation for initial microalgae density greater than $50 \mathrm{mg} \cdot \mathrm{L}^{-1}$ on days $0-4$ and $5-14$. This insignificant variation could be indicated by the specific growth rate of microalgae depending on the bacteria population and microalgae cells allowed to accelerate into the death phase. From Table 1, the initial concentration of Chlorella vulgaris was gradually increased almost causing cells to fall to the bottom of the culture flasks. Hence, the TSS 
values were measured over $90 \%$ as the initial microalgae density was added over $40 \mathrm{mg} \cdot \mathrm{L}^{-1}$. Moreover, at the initial cell concentration after $50 \mathrm{mg} \cdot \mathrm{L}^{-1}$, the growth rate of the bacteria population had not significantly increased compared to others, and this suggests that bacteria inhibited lipid accumulation. In the same culture conditions as illumination intensity, nutrients from SWE and aeration mode, depending on bacteria density were found gradually decreased in lipid contents with a higher growth rate of bacteria.
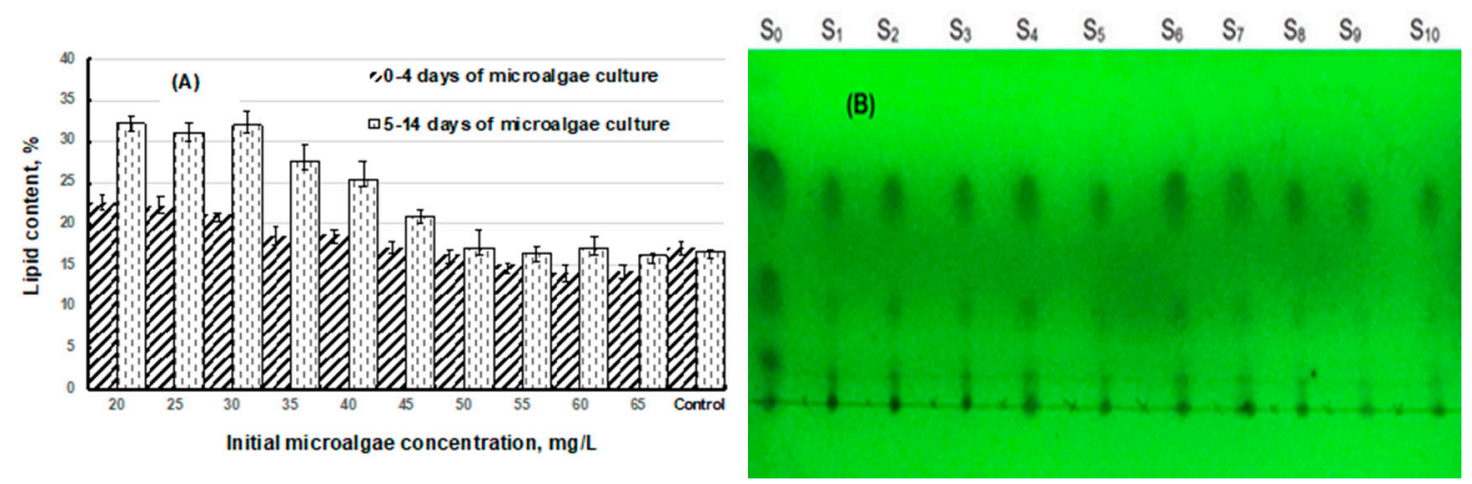

Figure 3. Lipid production in two phases of Chlorella vulgaris cultivation: exponential phase (0-4 days) and death phase (5-14 days); (A) Lipid concentration of microalgae measured in each sample, (B) TLC plate of lipid extracted; $S_{0}$ is the sample of green bean standard, $S_{1}$ to $S_{10}$ is the 1st sample to 10th sample corresponding to the TAG in lipid extract of initial microalga concentration from $20 \mathrm{mg} \cdot \mathrm{L}^{-1}$ to $65 \mathrm{mg} \cdot \mathrm{L}^{-1}$.

On the other hand, as shown in Figure 1, the growth rate of microalgae inoculum indicated a significant reduction and found that the low cell density weakened the lipid production. Obviously, pigment content depends on the cell density, and the chlorophyll was gradually decreased following the growth rate of microalgae. Meanwhile values of chlorophyll represent part of the total lipid content [22]. The chlorophyll contents of microalgae culture with initial cell density in band of $40 \mathrm{mg} \cdot \mathrm{L}^{-1}$ later were measured much lower among the others. For instance, at an initial cell concentration of $25 \mathrm{mg} \cdot \mathrm{L}^{-1}$, the chlorophyll a of suspension at day 5 was $17 \pm 10.3 \mathrm{mg} \cdot \mathrm{L}^{-1}$ compared to that of $65 \mathrm{mg} \cdot \mathrm{L}^{-1}$, which was only $9.85 \pm 0.12 \mathrm{mg} \cdot \mathrm{L}^{-1}$ (Table 1 ). Our results revealed that a higher bacteria content in the culture medium can inhibit microalgae growth and lipid production. In contrast, a high value of the initial cell content could not only enhance the auto-flocculation but was also beneficial to an efficient au-decantation.

\subsection{Effects of Total-N and Total-P to Lipid Production}

The roles of bacteria, the initial microalgae density interaction with cell lipid production, and the nitrogen and phosphorous of SWE nutrients were investigated in response to the variation of the growth rate of microalgae as well as the bacteria population. Table 2 presents the total-N and total-P removal on the specific growth rate of microalgae and bacteria population. Based on our results, the microalgae growth was poor following the low removal of nitrogen and phosphorus. A higher bacteria density in the culture caused a lower performance of nitrogen and phosphorus removal. In addition, the nitrogen starvation did not appear to create the optimal conditions for lipid accumulation [25]. Compared to the specific growth rate of Chlorella vulgaris inoculum in SWE, the microalgae biomass concentration did not increase following the initial cell density. The difficulty in the uptake of nutrients for cell division is represented by the total-N and total-P removal data. Meanwhile the bacteria population at a high initial microalgae density slowly decreased the specific growth rate, suggesting that the bacteria motivated to bloom microalgae and inhibited the macromolecules containing nitrogen or phosphorus (include lipid and protein) from transferring to the cell membrane. 
Table 2. The characteristics of SWE after 14 days of Chlorella vulgaris culture.

\begin{tabular}{ccccccccccccc}
\hline $\mathbf{C}_{\boldsymbol{i}} \mathbf{( m g} \cdot \mathbf{L}^{-\mathbf{1})}$ & $\mathbf{2 0}$ & $\mathbf{2 5}$ & $\mathbf{3 0}$ & $\mathbf{3 5}$ & $\mathbf{4 0}$ & $\mathbf{4 5}$ & $\mathbf{5 0}$ & $\mathbf{5 5}$ & $\mathbf{6 0}$ & $\mathbf{6 5}$ & $\mathbf{C o n t r o l}$ \\
\hline Total-N removal (\%) & $82.5 \pm 2.5$ & $81.8 \pm 5.6$ & $80.7 \pm 0.75$ & $70.17 \pm 1.2$ & $70.6 \pm 3.0$ & $66.66 \pm 0.5$ & $70.1 \pm 1.23$ & $57.84 \pm 2.25$ & $41.7 \pm 2.05$ & $41.8 \pm 0.5$ & $38.3 \pm 0.35$ \\
\hline Total-P removal (\%) & $77.71 \pm 0.5$ & $79.02 \pm 0.45$ & $78.4 \pm 1.05$ & $75.33 \pm 0.5$ & $71.47 \pm 0.72$ & $66.07 \pm 0.5$ & $62.22 \pm 0.32$ & $63.76 \pm 0.75$ & $59.9 \pm 0.5$ & $57.59 \pm 0.24$ & $48.34 \pm 0.67$ \\
\hline
\end{tabular}

$\mathrm{C}_{i}$ : Initial Chlorella vulgaris concentration or initial cell of Chlorella vulgaris density $\left(\mathrm{mg} \cdot \mathrm{L}^{-1}\right)$; Total-N: Total nitrogen of SWE concentration (mg. $\mathrm{L}^{-1}$ ); Total-P: Total phosphorous of SWE concentration $\left(\mathrm{mg} \cdot \mathrm{L}^{-1}\right)$. 
With the same initial concentration of total-N and total-P in SWE, the change of microalgae density resulted so differently in the efficiency removal of nitrogen and phosphorous. Compared to the initial cell density of $20 \mathrm{mg} \cdot \mathrm{L}^{-1}$, the nitrogen and phosphorous removal were at $82.5 \pm 2.5 \%$ and $77.71 \pm 0.5 \%$, respectively, while these removal performances obtained $41.8 \pm 2.01 \%$ for nitrogen data and $57.59 \pm 1.25 \%$ for phosphorous data at the initial microalgae concentration of $65 \mathrm{mg} \cdot \mathrm{L}^{-1}$. The existence of excessive nitrogen in culture medium inhibited the lipid accumulation of Chlorella vulgaris cells [35]. It was found that the reduction of nitrogen and phosphorous content in the SWE control was significantly slow compared to the one in SWE with microalgae (Table 2); the auto-reduction of nitrogen obtained $38.3 \pm 0.35 \%$ as just representing the bacteria community in SWE. These results proved that the high bacteria population inhibited the microalgae growth and acted as another parameter of the culture medium connecting the microalgae growth rate, the bacteria population growth and the analysis of nitrogen and phosphorous content. The presence of microorganism co-culture in the medium was well-documented but the limitation of their density was firstly investigated in this study.

\section{Conclusions}

Algae biorefinery is involved in the production of renewable biofuel by lipid accumulation in microalgae cultivation. Recently, algae research has aimed to enhance lipid production and economize the global cost of microalgae cultivation. This study shows an optimal lipid content attained at moderate Chlorella vulgaris density culture in SWE. This condition not only inhibited bacteria growth at the division phase, but also enhanced the lipid accumulation of Chlorella vulgaris at the death phase. In addition, the lipid content was approximately two times higher compared to that of the control $(16.8 \pm 0.5 \%)$. The success of this study could be expanded to develop wastewater treatment plants to convert SWE nutrient into highly economic, valued lipid through algae biorefinery.

Author Contributions: Conceptualization, T.D.P.N., D.H.N. and P.L.S.; Formal analysis, T.B.H.V.; Funding acquisition, J.W.L.; Investigation, T.T.C.N.; Methodology, T.N.T.T.; Project administration, J.W.L. and P.L.S.; Supervision, T.D.P.N.; Visualization, C.-K.C. and H.Y.L.; Writing—original draft, T.D.P.N. and D.H.N.; Writing-review \& editing, C.-K.C. and H.Y.L.

Funding: This research was funded by Universiti Teknologi PETRONAS, grant number YUTP-FRG (0153AA-E48) and Ministry of Education Malaysia under HICoE.

Acknowledgments: The authors would like to thank the colleagues from Faculty of Chemical and Environmental Engineering, Danang University of Technology and Education for their kindly help.

Conflicts of Interest: The authors declare no conflict of interest.

\section{References}

1. Mata, T.M.; Martins, A.A.; Caetano, N.S. Microalgae for biodiesel production and other applications: A review. Renew. Sustain. Energy Rev. 2010, 14, 217-232. [CrossRef]

2. Cheirsilp, B.; Torpee, S. Enhanced growth and lipid production of microalgae under mixotrophic culture condition: Effect of light intensity, glucose concentration and fed-batch cultivation. Bioresour. Technol. 2012, 110, 510-516. [CrossRef] [PubMed]

3. Shin, Y.S.; Choi, H.I.; Choi, J.W.; Lee, J.S.; Sung, Y.J.; Sim, S.J. Multilateral approach on enhancing economic viability of lipid production from microalgae: A review. Bioresour. Technol. 2018, 258, 335-344. [CrossRef] [PubMed]

4. Atta, M.; Idris, A.; Bukhari, A.; Wahidin, S. Intensity of blue LED light: A potential stimulus for biomass and lipid content in fresh water microalgae Chlorella vulgaris. Bioresour. Technol. 2013, 148, 373-378. [CrossRef] [PubMed]

5. Hultberg, M.; Jönsson, H.L.; Bergstrand, K.J.; Carlsson, A.S. Impact of light quality on biomass production and fatty acid content in the microalga Chlorella vulgaris. Bioresour. Technol. 2014, 159, 465-467. [CrossRef] [PubMed] 
6. Han, F.; Huang, J.; Li, Y.; Wang, W.; Wan, M.; Shen, G.; Wang, J. Enhanced lipid productivity of Chlorella pyrenoidosa through the culture strategy of semi-continuous cultivation with nitrogen limitation and $\mathrm{pH}$ control by $\mathrm{CO}_{2}$. Bioresour. Technol. 2013, 136, 418-424. [CrossRef] [PubMed]

7. Mujtaba, G.; Choi, W.; Lee, C.G.; Lee, K. Lipid production by Chlorella vulgaris after a shift from nutrient-rich to nitrogen starvation conditions. Bioresour. Technol. 2012, 123, 279-283. [CrossRef]

8. Xin, L.; Hong-ying, H.; Yu-ping, Z. Growth and lipid accumulation properties of a freshwater microalga Scenedesmus sp. under different cultivation temperature. Bioresour. Technol. 2011, 102, 3098-3102. [CrossRef]

9. Yeh, K.L.; Chang, J.S. Effects of cultivation conditions and media composition on cell growth and lipid productivity of indigenous microalga Chlorella vulgaris ESP-31. Bioresour. Technol. 2012, 105, 120-127. [CrossRef]

10. Widjaja, A.; Chien, C.C.; Ju, Y.H. Study of increasing lipid production from fresh water microalgae Chlorella vulgaris. J. Taiwan Inst. Chem. Eng. 2009, 40, 13-20. [CrossRef]

11. Feng, D.; Chen, Z.; Xue, S.; Zhang, W. Increased lipid production of the marine oleaginous microalgae Isochrysis zhangjiangensis (Chrysophyta) by nitrogen supplement. Bioresour. Technol. 2011, 102, 6710-6716. [CrossRef] [PubMed]

12. Feng, Y.; Li, C.; Zhang, D. Lipid production of Chlorella vulgaris cultured in artificial wastewater medium. Bioresour. Technol. 2011, 102, 101-105. [CrossRef] [PubMed]

13. Illman, A.M.; Scragg, A.H.; Shales, S.W. Increase in Chlorella strains calorific values when grown in low nitrogen medium. Enzyme Microb. Technol. 2000, 27, 631-635. [CrossRef]

14. Reitan, K.I.; Rainuzzo, J.R.; Olsen, Y. Effect of nutrient limitation on fatty acid and lipid content of marine microalgae. J. Phycol. 1994, 30, 972-979. [CrossRef]

15. Takagi, M.; Yoshida, T. Effect of salt concentration on intracellular accumulation of lipids and triacylglyceride in marine microalgae Dunaliella cells. J. Biosci. Bioeng. 2006, 101, 223-226. [CrossRef] [PubMed]

16. Prathima Devi, M.; Venkata Subhash, G.; Venkata Mohan, S. Heterotrophic cultivation of mixed microalgae for lipid accumulation and wastewater treatment during sequential growth and starvation phases: Effect of nutrient supplementation. Renew. Energy 2012, 43, 276-283. [CrossRef]

17. Shi, X.M.; Chen, F.; Yuan, J.P.; Chen, H. Heterotrophic production of lutein by selected Chlorella strains. J. Appl. Phycol. 1997, 9, 445-450. [CrossRef]

18. Nguyen, T.D.P.; Frappart, M.; Jaouen, P.; Pruvost, J.; Bourseau, P. Harvesting Chlorella vulgaris by natural increase in pH: Effect of medium composition. Environ. Technol. 2014, 35, 1378-1388. [CrossRef]

19. Nguyen, T.D.P.; Le, T.V.A.; Show, P.L.; Nguyen, T.T.; Tran, M.H.; Tran, T.N.T.; Lee, S.Y. Bioflocculation formation of microalgae-bacteria in enhancing microalgae harvesting and nutrient removal from wastewater effluent. Bioresour. Technol. 2018, 272, 34-39. [CrossRef]

20. Nguyen, T.D.P.; Tran, T.N.T.; Le, T.V.A.; Phan, T.X.N.; Show, P.L.; Chia, S.R. Auto-flocculation through cultivation of Chlorella vulgaris in seafood wastewater discharge: Influence of culture conditions on microalgae growth and nutrient removal. J. Biosci. Bioeng. 2019, 127, 492-498. [CrossRef]

21. Krzemińska, I.; Pawlik-Skowrońska, B.; Trzcińska, M.; Tys, J. Influence of photoperiods on the growth rate and biomass productivity of green microalgae. Bioprocess Biosyst. Eng. 2014, 37, 735-741. [CrossRef] [PubMed]

22. Pruvost, J.; Van Vooren, G.; Le Gouic, B.; Couzinet-Mossion, A.; Legrand, J. Systematic investigation of biomass and lipid productivity by microalgae in photobioreactors for biodiesel application. Bioresour. Technol. 2011, 102, 150-158. [CrossRef] [PubMed]

23. Hazan, R.; Que, Y.A.; Maura, D.; Rahme, L.G. A method for high throughput determination of viable bacteria cell counts in 96-well plates. BMC Microbiol. 2012, 12, 1. [CrossRef] [PubMed]

24. APHA/AWWA/WEF. Standard Methods for the Examination of Water and Wastewater. Available online: https://www.google.com.tw/url?sa=t\&rct=j\&q=\&esrc=s\&source=web\&cd=1\&cad=rja\&uact=8\& ved=2ahUKEwjH3bDW05ziAhVjF6YKHQuGDMMQFjAAegQIAhAC\&url=https\%3A\%2F\%2Fwww. researchgate.net\%2Fprofile\%2FArif_Reza\%2Fpost\%2FCan_you_give_me_the_APHA_method_for_ trace_metal_analysis\%2Fattachment\%2F59d63565c49f478072ea35b5\%2FAS\%253A273663767580673\% 25401442257934916\%2Fdownload\%2Fstandard\%2Bmethods\%2Bfor\%2Bthe\%2Bexamination\%2Bof\% 2Bwater\%2Band\%2Bwastewater\%2B\%25281000-3000\%2529.pdf\&usg=AOvVaw1054PsR-j-GFOAdqaW9sx (accessed on 20 April 2019). 
25. Van Vooren, G.; Le Grand, F.; Legrand, J.; Cuiné, S.; Peltier, G.; Pruvost, J. Investigation of fatty acids accumulation in Nannochloropsis oculata for biodiesel application. Bioresour. Technol. 2012, 124, 421-432. [CrossRef] [PubMed]

26. Wang, Y.; He, B.; Sun, Z.; Chen, Y.F. Chemically enhanced lipid production from microalgae under low sub-optimal temperature. Algal Res. 2016, 16, 20-27. [CrossRef]

27. Zhang, Y.; Su, H.; Zhong, Y.; Zhang, C.; Shen, Z.; Sang, W.; Yan, G.; Zhou, X. The effect of bacterial contamination on the heterotrophic cultivation of Chlorella pyrenoidosa in wastewater from the production of soybean products. Water Res. 2012, 46, 5509-5516. [CrossRef] [PubMed]

28. Ma, X.; Zhou, W.; Fu, Z.; Cheng, Y.; Min, M.; Liu, Y.; Zhang, Y.; Chen, P.; Ruan, R. Effect of wastewater-borne bacteria on algal growth and nutrients removal in wastewater-based algae cultivation system. Bioresour. Technol. 2014, 167, 8-13. [CrossRef]

29. Quijano, G.; Arcila, J.S.; Buitrón, G. Microalgal-bacterial aggregates: Applications and perspectives for wastewater treatment. Biotechnol. Adv. 2017, 35, 772-781. [CrossRef]

30. Fukami, K.; Nishijima, T.; Ishida, Y. Stimulative and inhibitory effects of bacteria on the growth of microalgae. Hydrobiologia 1997, 358, 185-191. [CrossRef]

31. Han, J.; Zhang, L.; Wang, S.; Yang, G.; Zhao, L.; Pan, K. Co-culturing bacteria and microalgae in organic carbon containing medium. J. Biol. Res.-Thessalon. 2016, 23, 8. [CrossRef]

32. Abinandan, S.; Subashchandrabose, S.R.; Venkateswarlu, K.; Megharaj, M. Nutrient removal and biomass production: Advances in microalgal biotechnology for wastewater treatment. Crit. Rev. Biotechnol. 2018, 38, 1244-1260. [CrossRef] [PubMed]

33. Alcántara, C.; Domínguez, J.M.; García, D.; Blanco, S.; Pérez, R.; García-Encina, P.A.; Muñoz, R. Evaluation of wastewater treatment in a novel anoxic-aerobic algal-bacterial photobioreactor with biomass recycling through carbon and nitrogen mass balances. Bioresour. Technol. 2015, 191, 173-186. [CrossRef] [PubMed]

34. Cai, T.; Park, S.Y.; Li, Y. Nutrient recovery from wastewater streams by microalgae: Status and prospects. Renew. Sustain. Energy Rev. 2013, 19, 360-369. [CrossRef]

35. Li, X.; Li, W.; Zhai, J.; Wei, H.; Wang, Q. Effect of ammonium nitrogen on microalgal growth, biochemical composition and photosynthetic performance in mixotrophic cultivation. Bioresour. Technol. 2019, 273, 368-376. [CrossRef] [PubMed] 